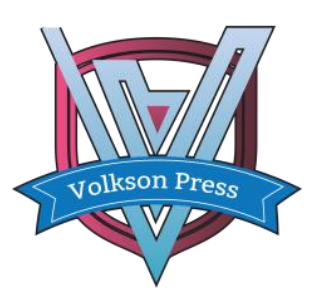

Contents List available at VOLKSON PRESS

Economics \& Management Innovations(EMI)

DOI : http://doi.org/10.26480/icemi.01.2017.247.249

\title{
A new way of thinking by company employees according to Lean Management concept
}

\author{
Agnieszka GRZELCZAK \\ Poznan University of Technology, Faculty of Engineering Management, Poland \\ agnieszka.grzelczak@put.poznan.pl
}

This is an open access article distributed under the Creative Commons Attribution License, which permits unrestricted use, distribution, and reproduction in any medium, provided the original work is properly cited.

\section{ARTICLE DETAILS}

\section{Article History:}

Received 02 october 2017 Accepted 06 october 2017

Available online 11 october 2017

\section{Keywords:}

Lean Management, traditional

and lean approaches to

production.

\section{ABSTRACT}

Lean Management is a management concept that creates a work culture at a company that makes all employees strive to continuously reduce costs, improve the quality and shorten delivery cycle to maximally meet customers' expectations and adapt to the environment by eliminating any waste identified and integrating the activities connected with the stream creating customer value. The article is aimed at presenting the results of research on the Lean Management concepts in an enterprise, in particular concerning traditional and lean approach to production, conducted among the personnel of enterprises from Wielkopolska Region, Poland.

\section{Introduction}

Improving processes means a constant research of possibilities for upgrading processes realized in everyday activity of the enterprise, as well as streamlining the relation between processes. These operations aim at consequences in form of improvements of the quality of products, the productivity of processes or reduction of costs of activities, in order to obtain finally the growth of efficiency of the entire organization $[1,2]$. The concept of Lean Management consists in continuous improvement. The article does not aim at presenting the concept itself, it only wants to show results of research on the evaluation of the way of thinking in categories of lean in reference to the traditional perception of solutions in the modern enterprise.

\section{The essence of Lean Management}

Lean Management is an idea on management that creates such culture of work in a company that makes everyone aspire to a continuous reduction of costs and upgrading the level of quality, as well as shortening the supply cycle in order to fully meet expectations of clients and adjust the functioning to external conditions and eliminate all wastes $[3,4,5]$. The concept of Lean Management is based on certain assumptions, called by a Polish author, Z. Martyniak [6], rules, or, named components by German authors F. Gendo and R. Konschak [7]. Womack [3] defines lean production as a system that creates value-added by using less of every input, which is based on the waste concept of the Japanese. Demeter and Matyusz [13] emphasize that lean production or lean enterprise emerges when the company implements lean development, procurement, manufacturing, and distribution together.

It is often said that Lean Management is a new way of thinking of employees in a company. This refers not only to managers, but also to the entire staff of the enterprise $[8,9,10]$. This is why it is worthwhile comparing the "old" (it means traditional) and "new" (meaning required) ways of thinking, for getting a better orientation, which are the basis of these differences.

3. Way of thinking characteristic for Lean Management - research results

There has been conducted determined research in order to evaluate the way of thinking (perception) in categories lean in comparison to the traditional approach to perceiving solutions in a modern enterprise. The research was run with use of a survey (questionnaire). The examined population was a group of employees of companies in the Wielkopolska Region (Poland), it enclosed 1200 participants. The analysis focused on results from 1050 respondents. The sample was established by random choice and the research was conducted in March and April 2015. Respondents were supposed to choose between two options, basing on their own professional experience. Results (along with the percentage share of the determined choice) are presented in the table no. 1.

Table 1. New and traditional way of thinking in accordance to the staff's opinion $(\mathrm{N}=1050)$

\begin{tabular}{|c|c|c|c|}
\hline New way of thinking & $\%$ & $\%$ & Traditional way of thinking \\
\hline $\begin{array}{r}\text { Planned tasks and } \\
\text { action are being } \\
\text { established during } \\
\text { discussion with } \\
\text { employees. }\end{array}$ & 74.03 & 25.97 & $\begin{array}{l}\text { The production plan and the } \\
\text { desired productivity are } \\
\text { being established top-down. }\end{array}$ \\
\hline $\begin{array}{r}\text { The cost cutting is taking } \\
\text { place thanks to the } \\
\text { increase in the } \\
\text { productivity of } \\
\text { employees. }\end{array}$ & 38.46 & 61.54 & $\begin{array}{l}\text { The cost cutting is being } \\
\text { achieved thanks for } \\
\text { investments and the } \\
\text { automation. }\end{array}$ \\
\hline $\begin{array}{r}\text { It is possible to achieve } \\
\text { progress only thanks to } \\
\text { the substantial amount of } \\
\text { simple solutions. }\end{array}$ & 28.17 & 71.83 & $\begin{array}{l}\text { Progress is possible } \\
\text { thanks to comprehensive } \\
\text { solutions. }\end{array}$ \\
\hline $\begin{array}{r}\text { Raw materials to } \\
\text { productions, in which } \\
\text { defects were displayed, } \\
\text { are being eliminated. }\end{array}$ & 65.00 & 35.00 & $\begin{array}{l}\text { Raw materials to } \\
\text { productions, in which } \\
\text { defects were displayed, are } \\
\text { being repaired in the } \\
\text { determined time. }\end{array}$ \\
\hline $\begin{array}{r}\text { Planning and organizing } \\
\text { of processes takes place } \\
\text { determining on the } \\
\text { situation. }\end{array}$ & 39.73 & 60.27 & $\begin{array}{l}\text { Planning and organizing } \\
\text { of processes is a task that } \\
\text { belongs to the managerial } \\
\text { staff. }\end{array}$ \\
\hline $\begin{array}{r}\text { Errors are deleted } \\
\text { instantly and wastes } \\
\text { eliminated }\end{array}$ & 74.32 & 25.68 & $\begin{array}{l}\text { Errors and wastes occur in } \\
\text { every system. }\end{array}$ \\
\hline $\begin{array}{r}\text { The employee feels that } \\
\text { he is responsible for } \\
\text { costs. }\end{array}$ & 64.38 & 35.62 & $\begin{array}{l}\text { The employee usually } \\
\text { doesn't feel the } \\
\text { responsibility for costs. }\end{array}$ \\
\hline
\end{tabular}

Source: own study based on research results.

The analysis of obtained results concerning set patterns of thinking in modern enterprises shows that there is no clear "tilt" of results in any of 
available options. The amount of responses pointing at the new and the traditional way of thinking was almost divided into half, only slightly lurching into the side of new ways of thinking, characteristic for the concept of Lean Management (four of seven aspects, i.e. almost 55\% of answers).

In the area of planning operations, respondents were showing that planned tasks and operations are being established throughout discussions with the staff $(74.03 \%$ indications $)$, not top-down. However, the planning and the organizing of processes belongs to managers $(60.27 \%)$, instead of taking place depending on the changing situation and in co-participation of the staff. In the area of costs, respondents showed that although an employee feels the responsibility for costs $(64.38 \%$ indications), the reduction of costs results from investments and automation (61.54\%), not from the growth of productivity of employees. In the care of the quality of products of the company, employees declared that errors are instantly deleted and wastes are eliminated (74.32\%) and raw materials with defects are eliminated (65\%) instead of being repaired in a defined time. Unfortunately, respondents pointed at the fact that the progress is possible only thanks to comprehensive solutions $(71.83 \%$ indications), without noticing that it can be also obtained thanks to numerous simple solutions $(28.17 \%)$ - so characteristic in Lean Management.

The analysis of data allowed selecting results obtained from respondents employed at the managerial level and the group of respondents from the executive staff. These results are presented in the table 2 . The distribution of responses among employees from the managerial and executive level agrees with total results, even though percentage shares for individual indications differ in both groups.

\section{Table 2. New and traditional way of thinking in the opinion of people} employed as executive staff $(\mathrm{N}=640$, upper line) and people employed as managers $(\mathrm{N}=\mathbf{2 2 0}$, lower line)

\begin{tabular}{|c|c|c|c|}
\hline New way of thinking & $\%$ & $\%$ & Traditional way of thinking \\
\hline \multirow{2}{*}{$\begin{array}{r}\text { Planned tasks and } \\
\text { action are being } \\
\text { established during } \\
\text { discussion with } \\
\text { employees. }\end{array}$} & 80.36 & 19.64 & \multirow{2}{*}{$\begin{array}{l}\text { The production plan and the } \\
\text { desired productivity are } \\
\text { being established top-down. }\end{array}$} \\
\hline & 57.14 & 42.86 & \\
\hline \multirow{2}{*}{$\begin{array}{r}\text { The cost cutting is taking } \\
\text { place thanks to the } \\
\text { increase in the } \\
\text { productivity of } \\
\text { employees. }\end{array}$} & 43.10 & 56.90 & \multirow{2}{*}{$\begin{array}{l}\text { The cost cutting is being } \\
\text { achieved thanks for } \\
\text { investments and the } \\
\text { automation. }\end{array}$} \\
\hline & 24.75 & 75.25 & \\
\hline \multirow{2}{*}{$\begin{array}{r}\text { It is possible to achieve } \\
\text { progress only thanks to } \\
\text { the substantial amount of } \\
\text { simple solutions. }\end{array}$} & 29.41 & 70.59 & \multirow{2}{*}{$\begin{array}{l}\text { Progress is possible } \\
\text { thanks to comprehensive } \\
\text { solutions. }\end{array}$} \\
\hline & 24.75 & 75.25 & \\
\hline \multirow{2}{*}{$\begin{array}{r}\text { Raw materials to } \\
\text { productions, in which } \\
\text { defects were displayed, } \\
\text { are being eliminated. }\end{array}$} & 66.10 & 33.90 & \multirow{2}{*}{$\begin{array}{l}\text { Raw materials to } \\
\text { productions, in which } \\
\text { defects were displayed, are } \\
\text { being repaired in the } \\
\text { determined time. }\end{array}$} \\
\hline & 61.90 & 38.10 & \\
\hline \multirow{2}{*}{$\begin{array}{r}\text { Planning and organizing } \\
\text { of processes takes place } \\
\text { determining on the } \\
\text { situation. }\end{array}$} & 43.40 & 56.60 & \multirow{2}{*}{$\begin{array}{l}\text { Planning and organizing } \\
\text { of processes is a task that } \\
\text { belongs to the managerial } \\
\text { staff. }\end{array}$} \\
\hline & 30.07 & 69.93 & \\
\hline \multirow{2}{*}{$\begin{array}{r}\text { Errors are deleted } \\
\text { instantly and wastes } \\
\text { eliminated. }\end{array}$} & 67.92 & 32.08 & \multirow{2}{*}{$\begin{array}{l}\text { Errors and wastes occur in } \\
\text { every system. }\end{array}$} \\
\hline & 90.48 & 9.52 & \\
\hline \multirow{2}{*}{$\begin{array}{r}\text { The employee feels that } \\
\text { he is responsible for } \\
\text { costs. }\end{array}$} & 60.38 & 39.62 & \multirow{2}{*}{$\begin{array}{l}\text { The employee usually } \\
\text { doesn't feel the } \\
\text { responsibility for costs. }\end{array}$} \\
\hline & 75.00 & 25.00 & \\
\hline
\end{tabular}

Source: own study based on research results.

It is worth pointing at the fact that responses in case of two factors are similar for executive staff and managers: results concerning the elimination of defects in raw materials $(66,10 \%$ indications for managers and $61,90 \%$ for the executive staff) and results for the way of obtaining the progress $(70,59 \%$ and $75,25 \%)$. One can observe that there are two points, in which answers differ significantly: for the thesis that planned tasks and operations are being established by discussing them with employees the diversity between results is $23 \%$ in favor to the managerial group (managers appreciate more the knowledge and the opinion of their employees - 80.36\%). However, the thesis that errors are eliminated instantly shows a difference of $23 \%$ in responses, but this time the answer was declared more often by executive staff $(90.48 \%)$.

\section{Summary}

The concept of Lean Management focuses on the process of making the value for the client. It is based on a substantial elimination of losses interpreted as operations for using assets without producing any value for the client.

Every use of materials for other purposes than the value for a client as a waste. Unlike in the traditional approach, which is based on high use of the production potential, Lean Management assumes producing only what is necessary (figure 1). This leads to the growth of productivity of the system improvement of the quality of offered products and the standard of the customer service becomes higher.

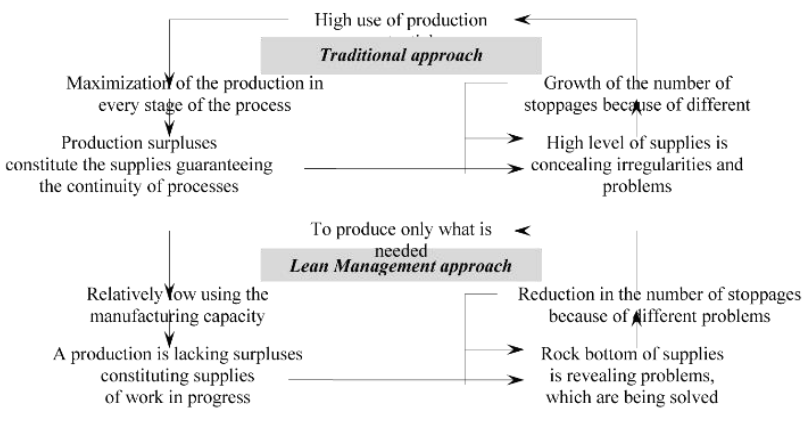

Figure 1. Comparing the traditional and lean approach towards the production [11]

Therefore, the basic aim of enterprise management in the concept of Lean Management is „To do more and more with less and less” [12] - in reference to assets, interpreted as total assets of the company: human resources, solid assets, production area, time, financial means, information, etc. The research run in the group of employees of Wielkopolska's enterprises show that both managers and executive staff notice the need of implementing the new way of thinking on the production and management in accordance to the concept of Lean Management, which means focusing on company's assets.

\section{References}

[1] B. Starzyńska, A. Hamrol, 2013, Excellence toolbox: Decision support system for quality tools and techniques selection and application. Total Quality Management \& Business Excellence 24(5) pp. 577-595

[2] Jasiulewicz-Kaczmarek M., 2014, Integrating Lean and Green Paradigms in Maintenance Management, in: Boje, Edward; Xia, Xiaohua (ed.) Proceedings of the 19th IFAC World Congress Cape Town, South Africa. August 24-29, 2014, IFAC-Papers OnLine Vol. 47(3) pp. 4471-4476

[3] J. Womack, D. Jones, D. Ross, The Machine that Changed the World: The Triumph of Lean Production; Rawson Macmillan: New York, NY, USA, 1990.

[4] C. Karlsson, P. Åhlström, 1996, Assessing changes towards lean production, International Journal of Operations \& Production Management 16, pp 24-41.

[5] M. Manzouri, M. N. Ab-Rahman, C.R.C.M. Zain, E. A. Jamsari, 2014, Increasing Production and Eliminating Waste through Lean Tools and Techniques for Halal Food Companies, Sustainability 6, pp. 9179-9204 [6] Z. Martyniak, Nowe metody i koncepcje zarządzania, Wydawnictwo AE w Krakowie, Kraków, 2002.

[7] F. Gendo, R. Konschak, Mythos Lean Production. Die wahren Erfolgskonzepte japanischer Unternehmen, Essen, 1999.

[8] J.M. Worley, T.L. Doolen, The role of communication and management support in a lean manufacturing implementation. Management Decision 2006, 44, pp. 228-245.

[9] M. Jasiulewicz-Kaczmarek, K. Szwedzka, Were our leaders ready to implement the changes? - a case study, in: Yue X.-G., Duarte N.J.R. (eds.) Proceedings of the 2016 International Conference on Economics and Management Innovations, part of Advances in Computer Science Research, 2016, vol. 57, pp. 267-271

[10] G. Kłosowski, A. Gola, A. Świć, Application of Fuzzy Logic in Assigning 
Workers to Production Tasks, in: Omatu S., et al. (eds.), Distributed Computing and Artificial Intelligence, 13th International Conference, Springer Series: Advances in Intelligent Systems and Computing, 2016, Vol. 474, pp. 505-513.

[11] E. Pająk, M. Klimkiewicz, A. Kosieradzka, Zarządzanie produkcją i usługami, PWE, Warszawa, 2014.
[12] J.P. Womack, D.T. Jones, Lean Thinking: Banish Waste and Create Wealth in Your Corporation. Simon \& Schuster, New York, 2003

[13] K. Demeter, Z. Matyusz, 2011, The impact of lean practices on inventory turnover. International Journal of Production Economics 2011, Vol. 133, pp. 154-163. 